many of their experiments were done in medium containing serum.

Our data support the hypothesis that it is the proteoglycan component of normal cartilage which prevents fibroblast adherence to the articular surface. The loss of proteoglycans from cartilage or other tissues during inflammation could create a suitable substrate for the migration of adjacent fibroblasts. Thus in rheumatoid arthritis, proteoglycan loss from cartilage may be a prerequisite for the invasion of the articular surface by synovial lining cells.

This work was supported by NIH grants AM 25776, AM 01431 (USPHS), HL 19721 and AM 11949. A.M.R. was supported by grant 5-T32CA-09161 from the NCI DHEW and NIH grant AI 17365. S.T.H. is the recipient of a Research Career Development Award (HL-00356).

Received 9 June; accepted 21 July 1981.

1. Pearlstein, E., Gold, L. I. \& Garcia-Pardo, A. Molec. cell. Biochem. 29, 103-128 (1980),

2. Gold, L. I. \& Pearlstein, E. Biochem. J. 186, 551-554 (1980).

3. Weiss, R. E. \& Reddi, A. H. J. Cell Biol. 88, 630-636 (1981)

4. Keiser, H. D. in The Cell Biology of Inflammation (ed. Weissmann, G.) (Elsevier/NorthHolland, Amsterdam, 1980).

5. Grinnell, F. Int. Rev. Cytol. 53, 65-144 (1978)

6. Toole, B. P. J. biol. Chem. 251, 896-897 (1976),

7. Culp, L. A., Murray, B. A. \& Rollins, B. J. J. supramolec. Struct. 11, 401-427 (1979).

8. Knox, P. \& Wells, P. J. Cell Sci. 40, 77-99 (1979)

9. Yamada, K. M. J. Cell Biol. 78, 520-541 (1978).

10. Pearlstein, E. Nature 262, 497-500 (1976).

11. Engvall, E. \& Ruoslahti, E. Int. J. Cancer 20, 1-5 (1977).

12. Rosenberg, L., Hellmann, W. \& Kleinschmidt, A. K. J. biol. Chem. 250, 1877-1883 (1975).

13. Pearlstein, E. \& Waterfield, M. D. Biochim. biophys. Acta 362, 1-12 (1974).

14. Pearlstein, E. \& Baez, L. Analgt. Biochem. (in the press).

15. Kleinman, H. K., McGoodwin, E. G., Rennard, S. I. \& Martin, G. R. Analyt. Biochem. 94, 308-312 (1979)

16. McConahey, P. J. \& Dixon, F. J. Int. Archs Allergy appl. Immun. 29, 185-189 (1966).

\section{Cell-specific drug transfer from liposomes bearing monoclonal antibodies}

\section{Lee D. Leserman, Patrick Machy \& Jacques Barbet}

Centre d'Immunologie INSERM-CNRS de Marseille-Luminy, Case 906, 13288 Marseille Cédex 9, France

Liposome-encapsulated drugs and fluorescent markers have been proposed as useful tools in studies of cell biology and in chemotherapy ${ }^{1-3}$. Until recently, this approach has been limited by the lack of means to fix protein ligands, such as antibodies, to liposome surfaces where they can mediate specific interactions with cells. Our newly developed technique ${ }^{4}$ for the covalent coupling of monoclonal antibodies to small, sonicated liposomes was used to study the specific delivery of methotrexate (MTX) to cellular targets in vitro. Liposomes containing MTX and carboxyfluorescein $(\mathrm{CF})^{5-7}$ were coupled to monoclonal antibodies against determinants of molecules encoded by the major histocompatibility complex of the murine $H-2^{\mathrm{k}}$ haplotype. These were incubated with lipopolysaccharide (LPS)-induced blast cells from CBA $\left(H-2^{k}\right)$, or C57BL/6 (B6) $\left(H-2^{b}\right)$ spleens. Only spleen cells from the CBA strain showed evidence of drug effect, as indicated by inhibition of radiolabelled deoxyuridine incorporation, demonstrating that the interaction of the liposomes with the cells was specific. With regard to the difierent determinants, the effect of the liposome-encapsulated MTX was not correlated with the number of liposomes bound to cells. More lipsomes became bound to the $\mathrm{H}-2 K^{k}$ molecule than to the H-2 I-Ek molecule, but liposomes bound to the latter were more effective for drug delivery. An endocytic pathway for the liposome-encapsulated drug is suggested by the fact that the effect of the drug in liposomes, but not in free form, was inhibited by the lysosomotropic amine, $\mathrm{NH}_{4} \mathrm{Cl}$. The techniques described here provide a simple quantitative assay for the 'endocytic potential' of any cell-surface determinant for which a ligand, such as an antibody or hormone, is available.
Murine IgG2a, $\kappa$ monoclonal antibodies 11-4-1 (ref. 8) (specificity for $\mathrm{H}-2 \mathrm{~K}^{\mathrm{k}}$ ) and $\mathrm{H} 40.242 .3$, which recognizes $\mathrm{H}-2$ $\mathrm{I}-\mathrm{E}^{\mathrm{k}}$, were coupled to liposomes containing MTX and CF using the heterobifunctional cross-linking reagent $N$-hydroxysuccinimidyl 3-(2-pyridyldithio) proprionate (SPDP), as described elsewhere ${ }^{4}$. Aliquots of the liposome preparations were added to duplicate cultures of LPS-induced blasts from CBA or B6 mice. After incubation, the amount of cell-associated CF was determined by fluorometry after detergent lysis of cells and liposomes ${ }^{5,9}$. Results are given in Table 1. Liposome binding was specific; CBA cells bound many more liposomes than did B6 cells, and the binding was inhibited by preincubation of the cells with the uncoupled homologous antibody, but not with an irrelevant antibody of the same class. The determinant recognized by the liposome-bound anti- $\mathrm{H}-2 \mathrm{~K}^{\mathrm{k}}$ antibody was richly represented on the CBA cells, the determinant recognized by the liposome-bound anti-H-2 I-E ${ }^{k}$ antibody being present in smaller amounts.

We next demonstrated that bound liposomes were capable of transferring their contents into the target cells. ${ }^{3} \mathrm{H}$-deoxyuridine $\left(\mathrm{d}\left[{ }^{3} \mathrm{H}\right] \mathrm{Urd}\right)$ uptake has been used as an index of MTX effect on tumour cells ${ }^{6,7}$. Using the same technique, LPS blasts were exposed to various concentrations of MTX in free solution or in antibody-bearing liposomes. As seen in Fig. $1 a, b$, cells from both mouse strains were sensitive to free MTX, but only CBA cells were sensitive to MTX in liposomes bearing anti-H-2 $\mathrm{K}^{\mathrm{k}}$ or anti-H-2 I-E $\mathrm{E}^{\mathrm{k}}$ antibodies. Furthermore, the magnitude of the drug effect was not directly related to the density of the target antigen: two times more anti- $\mathrm{H}-2 \mathrm{~K}^{\mathrm{k}}$ than anti-H-2 $\mathrm{I}-\mathrm{E}^{\mathrm{k}}$ antibody-bearing liposomes became associated with cells (Table 1), but the number of anti-H-2 $\mathrm{K}^{\mathrm{k}}$ antibody-bearing liposomes required for $50 \%$ inhibition of $\mathrm{d}\left[{ }^{3} \mathrm{H}\right] \mathrm{Urd}$ incorporation was four times greater. Thus, liposomes bound to the $\mathrm{H}-2 \mathrm{I}-\mathrm{E}^{\mathrm{k}}$ determinant were eight times more effective in drug delivery than

Table 1 Fluorescence of LPS blasts incubated with antibody-bearing liposomes containing carboxyfluorescein

$\begin{array}{lccc} & & \text { Cell-associated CF } \\ \text { (pmol) } & \text { Strain } \\ \text { Liposomes bearing } & \begin{array}{c}\text { Free antibody } \\ \text { in solution }\end{array} & \text { CBA } & \text { B6 } \\ 11-4-1 & \text { None } & 29 & 0.4 \\ 11-4-1 & 11-4-1 & 0.5 & \text { ND } \\ 11-4-1 & \text { B1.1G6 } & 25 & \text { ND } \\ \text { H40.242.3 } & \text { None } & 13.7 & 1.2 \\ \text { H40.242.3 } & \text { H40.242.3 } & 0.5 & \text { ND } \\ \text { H40.242.3 } & \text { B1.1G6 } & 14.5 & \text { ND }\end{array}$

Antibody B1.1G6 is IgG2a, $\kappa$ and is directed against human $\beta_{2}$-microglobulin It has no detectable binding to mouse spleen cells ${ }^{4}$. H40.242.3 (the gift of $M$. Pierres) is the product of a somatic cell hybrid between A.TH spleen cells hyperimmune to A.TL and the X63-Ag8.653 myeloma. It recognizes, on $\mathrm{H}-2$ $\mathrm{I}-\mathrm{E}^{\mathrm{k}}$-bearing cells, a determinant analogous to the $\mathrm{E} \alpha$ chain Ia.7 specificity. A detailed description of its binding properties will be reported elsewhere. All antibodies were purified on protein $\mathrm{A}$-Sepharose columns ${ }^{14}$. Small, sonicated liposomes composed of $65 \%$ (molar) dipalmitoyl-phosphatidylcholine, $34 \%$ cholesterol and $1 \%$ SPDP-modified phosphatidylethanolamine ${ }^{4}$, containing $40 \mathrm{mM} \mathrm{CF}$, were incubated with antibodies modified with $5 \mathrm{~mol}$ SPDP per mol antibody, at a final antibody concentration of $175 \mu \mathrm{g} \mathrm{m}^{-1}$. In these conditions, $35-55 \%$ of the antibodies became liposome bound, which corresponds to averages of five to nine antibody molecules bound per liposome ${ }^{15}$. All coupling reactions resulted in at least $75 \%$ antibody-bearing liposomes, as revealed by liposome precipitation with Staphylococcus aureus, strain Cowan I (ref. 4). Spleen cells $\left(30 \times 10^{6}\right)$ from CBA or B6 mice were incubated in tissue culture flasks with $20 \mathrm{ml}$ of RPMI 1640 medium supplemented with $5 \%$ fetal calf serum (FCS), and $20 \mu \mathrm{g} \mathrm{ml}^{-1}$ of LPS from Escherichia coli (Difco). After $40 \mathrm{~h}$ incubation, cells were resuspended in the same medium without LPS at a concentration of $3 \times 10^{6}$ cells $\mathrm{ml}^{-1} \cdot 100-\mu \mathrm{l}$ aliquots were placed in flat-bottom wells of 96 -well microtitre plates (Linbro). $10 \mu \mathrm{l}$ of medium or antibody at a final concentration of $20 \mu \mathrm{g} \mathrm{ml}^{-1}$ were added to duplicate wells. After $15 \mathrm{~min}$ of preincubation, $10 \mu \mathrm{l}$ of antibodybearing liposomes containing a total of $220 \mathrm{pmol}$ CF (lipid concentration $0.25 \mathrm{mM}$, expressed as total lipid) were added. Cells were incubated for $3 \mathrm{~h}$ at $37^{\circ} \mathrm{C}$, after which binding had reached plateau levels. Cells were then washed three times by centrifiguation. The pellets were lysed using $0.5 \%$ Triton $\mathrm{X}-100$, and fluorescence measured on an Aminco SPF 500 spectrofluorometer (excitation $488 \mathrm{~nm}$, emission $520 \mathrm{~nm}$ ). Fluorescence calculations were based on a $20 \mathrm{nMCF}$ standard. Quantitatively similar results were obtained in six similar experiments using five different liposome preparations. ND, not determined. 
Fig. 1 To wells of microtitre plates containing $2 \times 10^{5} 40-\mathrm{h}$ LPS blasts in RPMI 1640 plus $5 \%$ FCS were added either free MTX or antibody-bearing liposomes containing $20 \mathrm{mM}$ MTX and $40 \mathrm{mM} \mathrm{CF}$, or $40 \mathrm{mM} \mathrm{CF}$ alone. The amount of liposome-encapsulated MTX actually used in culture was determined by measurement of the co-encapsulated $\mathrm{CF}$ by fluorescence after Triton lysis of liposomes. Liposome encapsulation of $\mathrm{CF}$ and MTX, and their leakage from liposomes, have been shown to be commensurate ${ }^{\gamma}$, and we have confirmed this for antibody-bearing liposomes using radiolabelled MTX (data not shown), $a, b$, After $3 \mathrm{~h}$ incubation at $37^{\circ} \mathrm{C}, 1 \mu \mathrm{Ci}$ of $\mathrm{d}\left[{ }^{3} \mathrm{H}\right] \mathrm{Urd}$ was added to cultures, and after 16 additional hours of culture, cells were collected and the concentration of incorporated $\mathrm{d}\left[{ }^{3} \mathrm{H}\right]$ Urd measured as described elsewhere ${ }^{6,7} . a$, CBA blasts; $b$, B6 blasts. 0 , Free MTX; $\boldsymbol{\Delta}$, MTX in anti-H-2 I-E ${ }^{k}$ antibody-bearing liposomes; O, MTX in anti-H-2 $\mathrm{K}^{\mathrm{k}}$ antibody-bearing liposomes; $\square$, MTX in antihuman $\beta_{2}$-microglobulin antibody-bearing liposomes; anti-H-2 I-E ${ }^{\mathrm{k}}$ antibody-bearing liposomes without MTX. For the representative experiment shown here, control CBA cells incorporated $102,000 \pm 2,000$ c..p.m. and B6 cells incorporated $\quad 74,000 \pm 1,400$ c.p.m. Results are the mean \pm s.d. unless smaller than the points as plotted. $c$, After $3 \mathrm{~h}$ incubation of CBA LPS blasts with free MTX or MTX in antibody-bearing liposomes, plates were centrifuged at 1,600 r.p.m. and washed three times. They were resuspended in fresh medium and pulsed with $d\left[{ }^{3} \mathrm{H}\right] \mathrm{Urd}$, and then collected as above. Control cells incorporated $81,000 \pm 2,000$ c.p.m. Free MTX; $\boldsymbol{\Delta}$, MTX in anti-H-2 I-E ${ }^{k}$ antibody-bearing liposomes; $\mathrm{O}, \mathrm{MTX}$ in anti- $\mathrm{H}-2 \mathrm{~K}^{\mathrm{k}}$ antibody-bearing liposomes.

$d, \mathrm{NH}_{4} \mathrm{Cl}$ (10 mM final concentration) was added to weHs containing CBA LPS blasts 15 min before addition of free MTX or MTX in anti-H-2 I-E ${ }^{\mathrm{k}}$ antibody-bearing liposomes. Control cells incubated with $10 \mathrm{mM} \mathrm{NH}_{4} \mathrm{Cl}$ alone incorporated 82,000 c.p.m. antibody-bearing liposomes; $\triangle, \mathrm{MTX}$ in anti-H-2 I-E $\mathrm{E}^{\mathrm{k}}$ antibody-bearing liposomes plust $\mathrm{NH}_{4} \mathrm{Cl}$.

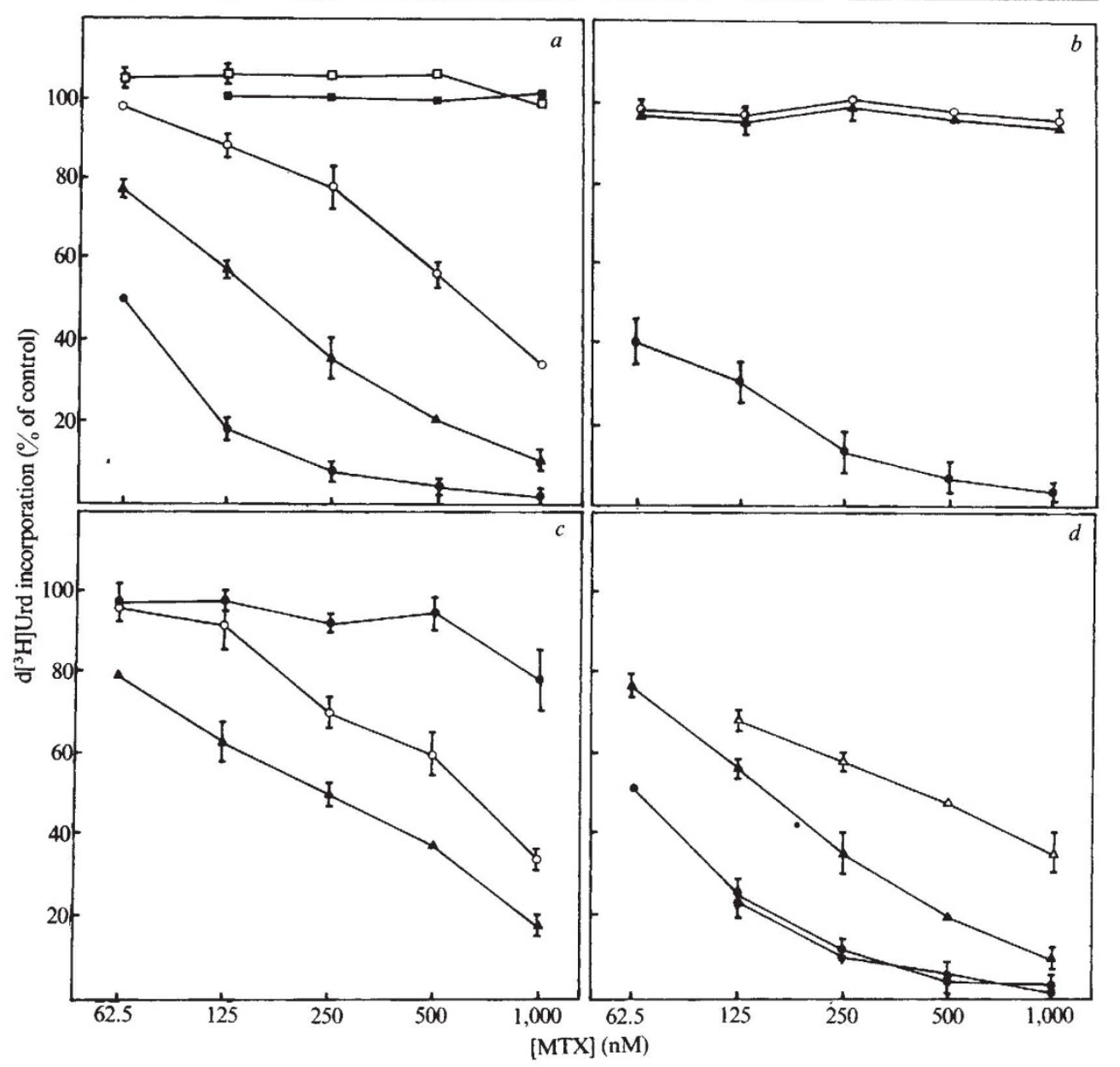

those bound to the $\mathrm{H}-2 \mathrm{~K}^{\mathrm{k}}$ determinant. Neither anti-H-2 $\mathrm{K}^{\mathrm{k}}$ nor anti-H-2 I-E ${ }^{k}$ antibody-bearing liposomes lacking MTX had any effect on $\mathrm{d}\left[{ }^{3} \mathrm{H}\right] \mathrm{Urd}$ incorporation. As expected from the effect on binding shown in Table 1 , anti-H-2 $\mathrm{K}^{\mathrm{k}}$ or anti-H-2 I- $E^{k}$ antibodies in free solution blocked the drug effects of liposomes bearing the homologous antibody. The anti-human $\beta_{2}$-microglobulin antibody in free solution had no effect on MTX delivery (data not shown).

The greater efficiency in drug delivery of anti-H-2 I-E antibody-bearing, as opposed to anti- $\mathrm{H}-2 \mathrm{~K}^{\mathrm{k}}$ antibody-bearing, liposomes seems to be a property of the target determinant and is not related to some peculiarity of these antibodies, as verified by the use of panel of monoclonal antibodies directed at the same molecule (data not shown).

The mechanism of entry into cells of the liposome-encapsulated drug was investigated. Cells were incubated with free MTX or with MTX in antibody-bearing liposomes for 3-4 h, then non-bound drug was washed away. As seen in Fig. $1 c$, the effect of the free MTX was largely eliminated, but the liposomebound drug was as effective as in the experiment shown in Fig. $1 a$, in which non-bound liposomes were not washed away. As we know that the number of liposomes bound is only a fraction of those present in culture (Table 1), the drug effect cannot be due to simple leakage of MTX from cell-bound liposomes. This is further suggested by the fact that the quantitatively more important determinant is a poorer target for liposome-bound drug, and by our previous demonstration that another cellsurface determinant (surface immunoglobulin of myeloma tumour cells) did not mediate drug transfer ${ }^{9}$.

$\mathrm{We}^{6}$ and others ${ }^{10}$ have observed the apparent delivery of antibody-opsonized liposomes to lysosomes of phagocytic tumour cells. That liposomes bound to LPS blasts, which are of B-cell origin, might also be delivered to lysosomes was suggested by an experiment using the lysosomotropic amine, $\mathrm{NH}_{4} \mathrm{Cl}$. When blast cells incubated with $10 \mathrm{mM} \mathrm{NH}_{4} \mathrm{Cl}$ were exposed to liposomes bearing the anti-H-2 I-E $E^{k}$ antibody, the drug effect was markedly reduced ( $65-70 \%$ over a series of experiments). There was no effect of $\mathrm{NH}_{4} \mathrm{Cl}$ on the number of cell-bound liposomes, as shown by experiments of the type described in Table 1 legend (data not shown).

A possible explanation for the selective effect of $\mathrm{NH}_{4} \mathrm{Cl}$ on liposome-encapsulated drug is provided by the ability of $\mathrm{NH}_{4} \mathrm{Cl}$ to neutralize lysosomal $\mathrm{pH}^{11}$. When delivered into lysosomes at their normal, acidic $p \mathrm{H}$, the anionic MTX would be protonated, and could thus diffuse out of lysosomes to its cytoplasmic site of action. If the lysosomal $\mathrm{pH}$ were neutral, this mode of entry would largely be eliminated. We do not exclude other mechanisms of action for $\mathrm{NH}_{4} \mathrm{Cl}$, such as inhibition of lysosomal enzymes or a direct effect on phagocytosis. It is unknown whether the apparent internalization of the $\mathrm{H}-2 \mathrm{I}-\mathrm{E}^{\mathrm{k}}$ molecule is related to the physiological role of $\mathrm{H}-2 \mathrm{I}-\mathrm{E}$ determinants (or of Ia molecules in general) in the regulation of cell interactions and of antigen presentation in the immune response $\mathrm{e}^{12,13}$.

MTX was provided by the Drug Synthesis and Chemistry Branch, Division of Cancer Treatment, NCI. This research was supported by INSERM and CNRS institutional grants, by a contract under the programme INSERM-NCI Recherches Cliniques en Cancérologie and by a grant from Association pour le Développement de la Recherche sur le Cancer. We thank Michel Pierres and Bernard Malissen for monocional antibodies and our colleagues at the Centre d'Immunologie for helpful discussions. 
Received 11 May; accepted 30 July 1981.

1. Gregoriadis, G. (ed.) Drug Carriers in Biology and Medicine (Academic, London, 1979). 2. Gregoriadis, G. \& Allison, A. C. (eds) Liposomes in Biological Systems (Wiley, New York, 1980).

3. Tom, B. H. \& Six, H. R. (eds) Liposomes and Immunobiology (Elsevier, Amsterdam, 1980). 4. Leserman, L. D., Barbet, J., Kourilsky, F. M. \& Weinstein, J. N. Nature 288, 602-604 (1980).

5. Weinstein, J. N., Blumenthal, R., Sharrow, S. O. \& Henkart, P. Biochim. biophys. Acta 509 272-288 (1978)

6. Leserman, L. D., Weinstein, J. N., Blumenthal, R. \& Terry, W. D. Proc. natn. Acad. Sci. U.S.A. 77, 4089-4093 (1980).

7. Leserman, L. D., Weinstein, J. N., Moore, J. J. \& Terry, W. D. Cancer Res. 40, 4768-4774 (1980).

8. Oi, V. T., Jones, P. P., Goding, J. W., Herzenberg, L. A. \& Herzenberg, L. A. Curr. Topics Microbiol. Immun. 81, 115-129 (1978).

9. Leserman, L. D., Weinstein, J. N., Blumenthal, R., Sharrow, S. O.\& Terry, W. D. J. Immun. 122, 585-591 (1979).

10. Lewis, J. T., Hafemann, D. G. \& McConnell, H. M. Biochemistry 19, 5376-5386 (1980)

11. Ohkuma, S. \& Poole, B. Proc. natn. Acad. Sci. U.S.A. 75, 3327-3331 (1978).

12. Martinez-A., C., Coutinho, A. \& Bernabe, R. R. Immunogenetics 10, 299-303 (1980).

13. Sprent, J. \& Alpert, B. J. exp. Med. 153, 823-830 (1981).

14. Goding, J. W. J. immun. Meth. 20, 241-253 (1978).

15. Barbet, J., Machy, P. \& Leserman, L. D. J. supramolec. Struct. cell. Biochem. (in the press).

\section{Genetic modification of potassium channels in Drosophila Shaker mutants}

\section{Lawrence Salkoff \& Robert Wyman}

Department of Biology, Yale University, Box 6666, New Haven, Connecticut 06511, USA

Previous research in Drosophila has implied that a variety of mutations affect ion channels ${ }^{1-4}$. In one of these studies it was suggested that mutations mapping at the X-linked Shaker locus of $D$. melanogaster might cause defects in some type of potassium channel in larval motoneurones ${ }^{2}$. We show here, by voltage-clamp analysis, that mutations at the Shaker locus affect one of the two types of voltage-sensitive potassium channels present in the Drosophila dorsal longitudinal flight muscle (DLM). Initial voltage-clamp studies ${ }^{3,6}$ revealed that one set of channels carries a fast, transient outward current, similar to the molluscan $A$ current ${ }^{7-9}$, that is altered by mutations at the Shaker locus. The other set of channels carries a slower activating current, similar to delayed rectification ${ }^{10,11}$, that is not affected by the Shaker mutation.

The mutant strains used were $S h^{r K O 120}$ and $S h^{K S 133}$ (ref. 2; from Dr Seymour Benzer), and $S h^{5}$ (ref. 12; from Dr David Suzuki). Wild-type stocks were used for comparison purposes (from Dr Donald Poulson) and included Canton-S, Oregon-R, Noumea and Canberra. The effects of the Shaker mutations on the potassium currents in the DLM were analysed by voltageclamp techniques as described elsewhere ${ }^{5,6}$. All experiments were performed at $4^{\circ} \mathrm{C}$. To study the A current in isolation from other currents, we selected animals at $\sim 70$ to $80 \mathrm{~h}$ of pupal development, a stage at which the A current is prominent but delayed rectification is small or absent ${ }^{6}$.

Voltage-clamp experiments showed that the $S h^{5}$ mutation greatly accelerates the rate at which the A-current channels inactivate and the rate at which they recover from inactivation. Other properties of the channels are not apparently affected. A comparison of A current in wild-type and $S h^{5}$ DLM is shown in Fig. 1; the current responses were evoked by voltage-clamp step pulses to different voltages from a holding potential of $-80 \mathrm{mV}$. The A-current channels open (activate) rapidly, but close (inactivate) over a slower time course. The rapid activation of the A current can be seen in the upper traces of Fig. $1 a, b$ as the very rapid rise (upwards) of the current to its peak. Inactivation is seen as the exponential decay (downwards) of the current from its peak. At each voltage level the inactivation of the channels occurs about twice as rapidly in $S h^{5}$ than in wild-type muscle fibres. The current trace that falls below the baseline is the current response evoked by a $100-\mathrm{mV}$ hyperpolarizing voltageclamp step pulse; it is the same in $a$ and $b$ of Fig. 1, showing that the input resistance is almost identical in $S h^{5}$ and wild-type cells.

Figure 2 compares the inactivation time constants measured at different voltages for the different genotypes. The time constants for $S h^{5} / S h^{5}$ muscle cells (solid symbols) were about half those of wild-type muscle cells (open symbols). Four different wild-type strains were used as a control to detect any scatter due to natural variation. In no case did a data point obtained for a wild-type muscle cell overlap with one obtained for a $S h^{5}$ muscle cell.

In addition to its effect on reducing channel inactivation time, the $S h^{5}$ mutation also shortens the time required to recover from inactivation. Recovery of inactivation was investigated in a two-pulse experiment. The ratio of the peak A current during the second pulse to that during the first was plotted against the inter-pulse interval. The longer the interval, the larger the ratio; recovery followed an approximately exponential time course with time constants ( \pm s.d.) of $633 \pm 21 \mathrm{~ms}(N=3)$ for wild-type, $485 \pm 59 \mathrm{~ms}(N=4)$ for heterozygotes, and $351 \pm 30 \mathrm{~ms}(N=4)$ for homozygous mutants.

Although the properties of inactivation and recovery are affected by the $S h^{5}$ mutation, other properties of the channels are not obviously affected. Both wild-type and mutant cells showed a similar voltage-dependence of steady-state inactivation, with $50 \%$ inactivation at $\sim-42 \mathrm{mV}$. A comparison of the current-voltage relationships for the peak of the A current
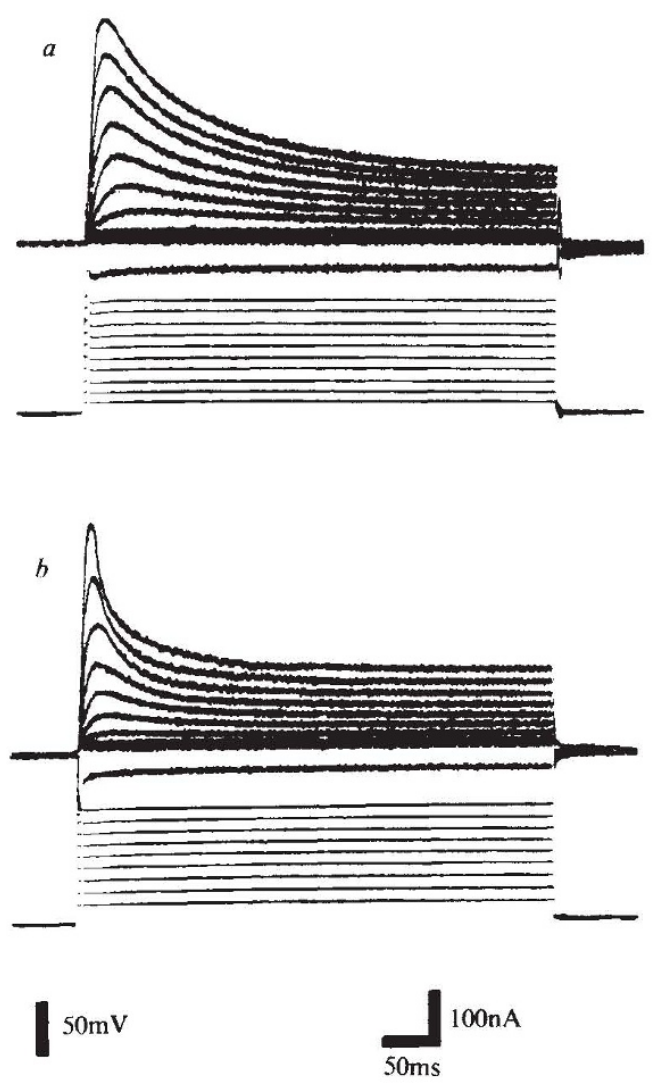

Fig. 1 Comparison of A-current responses to voltage-clamp step pulses in wild-type $(a)$ and $S h^{5}(b)$ animals. The holding potential is $-80 \mathrm{mV}$. Ten traces are shown in which single voltage-step pulses were applied to the membrane (lower traces); the membrane current response is shown in the upper traces. Outward currents are in the upward direction. Each of the current traces shows the membrane response at a different voltage level. (The voltage records for hyperpolarizing pulses to $-180 \mathrm{mV}$ are not shown.) 